\title{
SYSTÉM KOLEGIÁLNÍ PODPORY POLICIE ČR ${ }^{1}$
}

\author{
Petra Karbanová
}

\begin{abstract}
Abstrakt
Tato výzkumná studie se zabývá kolegiální podporou coby druhem sociální opory u bezpečnostního sboru. Kolegiální podporou se rozumí poskytování psychické podpory policistům a zaměstnancům, kteří jsou v komplikované, psychicky náročné životní situaci. Spočívá v nabídce rozhovoru, sdílení pocitů a problémů, konkrétní pomoci či informacích, eventuálně zprostředkování psychologické pomoci. Jejím cílem je předcházet rozvoji psychických obtíží policistů a zaměstnanců a rozšírít možnost psychické podpory. Výzkumná studie shrnuje základní zdroje stresu, se kterými se policisté potýkají a zároveň i stručně představí specifika policejní kultury, která u kolegiální podpory hraje důležitou roli. Následně je představena i česká praxe. Výzkum byl proveden pomocí polostrukturovaných rozhovorů s devíti poskytovateli kolegiální podpory ve Středočeském kraji, který jako první zavedl kolegiální podporu do systému psychologické péče o policisty. Analýza rozhovorů přinesla odpovědi na výzkumné otázky týkající se motivace policistů zapojit se do systému kolegiální podpory, vnímaní pozice kolegiální podpory v rámci policejní kultury a dovedností získaných v průběhu vstupního školení. Vedle témat výzkumných otázek se objevila i další důležitá témata jako je mlčenlivost, limity kolegiální podpory, její propagace, osobnost poskytovatele apod. Výsledky poukazují na místa v systému kolegiální podpory, jejichž propracování a prohloubení může přispět k úspěšnému vybudování komplexního systému kolegiální podpory u Policie ČR.
\end{abstract}

Klíčová slova: peer support, kolegiální podpora, sociální opora, policie

\section{THE PEER SUPPORT SYSTEM BY THE POLICE OF THE CZECH REPUBLIC}

Abstract

Research paper the Peer Support System by the Police of the Czech Republic deals with peer support as a kind of social support for the safety forces. Peer support means providing psychological support to policemen and employees who are in a complicated, psychologically challenging life situation. It consists of offering an interview, sharing feelings and problems, any specific help or information, or possibly providing psychological help. Its goal is to prevent the development of psychological difficulties for police officers and employees and to extend possibilities of psychological support. The research paper summarizes the basic sources of stress the cops face, and at the same time briefly introduces the specifics of the police culture that plays an important role in peer support. Further the Czech practice is described. The research was conducted through semi-structured interviews with nine peer support providers in the Central Bohemian Region, where the system of peer support was first introduced as a new way of psychological care for police officers. The analysis of interviews brought responses to research issues related to motivation of police officers to engage in the Peer Support System, perception of the position of the peer support within the police culture and skills acquired during initial training. Besides the topics of research questions, other important topics appeared such as confidentiality, limits of peer support, promotion, personality of the provider, etc. The results point to areas in the Peer Support System, whose elaboration and deepening can contribute to the successful establishment of a comprehensive system of the Peer Support System by the Police of the Czech Republic.

Keywords: peer support, social support, police

Došlo: 6. 3. 2019

Schváleno: 22. 6. 2019

\footnotetext{
${ }^{1}$ Článek vychází z diplomové práce: Karbanová, P. (2019). Systém kolegiální podpory Policie ČR. Praha: Filozofická fakulta Univerzity Karlovy.
} 


\section{Úvod}

V současné době stojí psychologická péče o policisty na třech pilíríich: služby policejních psychologů, Linka pomoci v krizi a systém kolegiální podpory. Co se týče péče o policisty na místě mimořádné události, tu poskytuje systém krizové intervence. Jeho smyslem je jednak se postarat o lidi zasažené mimořádnou událostí, jednak poskytnout psychickou podporu policistům, kteří u této události zasahují. Nicméně, právě systém kolegiální podpory je poměrně nový způsob péče o duševní zdraví policistů zaveden Pokynem policejního prezidenta č. 231/2016, o psychologických službách. Proto do současné doby zatím nebyla zpracována žádná studie, která by se touto novinkou u Policie ČR zabývala. Tato skutečnost se stala podnětem pro vznik předkládané výzkumné práce. Kolegiální podpora vychází z principu sociální opory, kterou lze vymezit jako „....pomoc, která je poskytovaná druhými lidmi člověku, který se nacházi $v$ zátěžové situaci. Obecně jde o činnost, která člověku v tísni jeho zátěžovou situaci určitým způsobem ulehčuje“ (Křivohlavý, 2001, s. 94). Sociální opora člověku uspokojuje různé sociální potřeby. Podle Křivohlavého (2001) jimi jsou potřeba přátelských vztahů, vzájemnosti, komunikace, kladného sociálního hodnocení, apod. Autor rovněž uvádí, že lze na sociální podporu pohlížet ze třech různých úrovní, a to makroúrovně, mezoúrovně a mikroúrovně. Kolegiální podpora svým principem spadá do rozmezí mezo a mikroúrovně. Uvažujeme-li kolegiální podporu jako formální systém podpory zavedený do organizace ozbrojených složek státu, spadá do mezoúrovně, tedy úrovně vztahů v rámci sociální skupiny, která pomáhá svým členům. Z hlediska interakce jednotlivých poskytovatelů lze hovořit o mikroúrovni, tedy o intimních vtazích mezi jedinci, kteří sdílí sociální oporu v rámci dyády.

Policejní profese klade na člověka velké nároky a očekávání, a to jak ze strany veřejnosti, tak ze strany samotné organizace. Policista je však také člověk, který má vedle svého profesního života i život soukromý, který více či méně ovlivňuje jeho pracovní výkon. Zdrojů stresu je ve výkonu služby u policistů několik. Jednak je to stres spojený s každodenním výkonem služby, kdy se policisté pravidelně setkávají s různými stresovými situacemi, ve kterých by měli umět dostatečně ovládat své emoce, at' už jednají s obět'mi, svědky či ozbrojenými podezřelými (Waters \& Ussery, 2007), jednak je to stres organizační, přičemž výzkumy ukazují (McCreary \& Thompson, 2006; Pienaar, Rothman \& Van de Vijver, 2007), že ve skutečnosti jsou velkým zdrojem stresu organizační faktory než samotný výkon služby. Jedná se např́klad o nutnost vypořádání se s několika konkurenčními požadavky současně a porozumění určitým náležitostem (Duxbury \& Higgins, 2012), dále nedostatek podpory ze strany nadř́zeného a s tím související nízká úroveň komunikace a možnost konzultace práce, nízká kontrola pracovní zátěže a pracovní přetížení (Collins \& Gibb, 2003). Violanti a Aron (1995) ještě dodávají, že ke zvýšené stresové zátěži napomáhá i nemožnost policistů účastnit se rozhodovacích procesů, práce na směny a neadekvátní podpora organizace (ve formě materiálního zabezpečení). Vedle profesní stránky, kde se policisté potýkají se zvýšenou zátěží, ještě žijí i své soukromé životy, kde přirozeně také prochází různými fázemi krizí i št'astnými chvílemi, které se mohou odrážet v pracovním výkonu policisty znatelněji než u jiných profesí.

Specifikem policejní práce je také policejní kultura. V jistém slova smyslu by se dalo hovořit o tzv. policejní subkultuře, která vznikla v závislosti na specifickém pracovním prostředí v uzavřeném sociálním systému homogenních sociálních skupin, které se formují v rámci jednotlivých policejních oddělení (McGuffin, 2018). Na policejní kulturu však nelze pohlížet jako na neměnný homogenní celek, kterým jsou nově příchozí příslušníci pasivně pohlceni, 
nýbrž jako na dynamický organismus, kdy nově př́íchozí přidávají do mozaiky hodnot své individuální hodnoty a přesvědčení, které mohou být v budoucnu využity jako zdroj v procesu rozhodování (Chan, 1996; Shearing \& Ericson, 1991). Chan (2007) rovněž připomíná, že policisté a potažmo policejní subkultury jsou ovlivňovány širším okolím a jeho normami. Stejně jako je veřejností považováno psychické onemocnění za stigmatizující, v policejní kultuře tomu není jinak (White, 2016). Proto při psychických obtíží policisté odbornou pomoc nevyhledají (Alexander \& Walker, 1994). Ve výzkumu však Karaffa a Tochkov (2013) zjistili, že někteří policisté soukromě tento názor nemají, nicméně jak se ukazuje, kultura pracovního prostředí převáží názory několika jednotlivců, a tak udržuje status quo v pohledu na vyhledání odborné psychické pomoci. Je obtížné skrze několika názorů jednotlivců bojovat proti stigmatu na celospolečenské úrovni, navíc ve skupině, kde jen náznak projevu slabosti je rovněž stigmatizující (Link \& Phelan, 2001).

V České republice před kolegiální podporou poměrně dlouhou dobu fungoval systém tzv. Posttraumatické intervenční péče (PIP). Jeho smyslem bylo minimalizovat rizika, která jsou spojená s nároky policejní práce. Členové týmu PIP byli připraveni poskytnout policistům potřebnou podporu a pomoc v situacích, kdy v rámci plnění pracovních úkolů byli vystavováni mimořádným událostem. Jejich snahou bylo pomáhat policistům zvládat jejich náročnou práci, lépe se vyrovnávat se zátěží, akutní stresovou reakcí a využívat k tomu všech informací a získaných zkušeností. Tvořili jej interventi z řad policistů, občanských zaměstnanců Ministerstva vnitra ČR a PČR, policejní psychologové a duchovní, kteř́ prošli speciálním výcvikem. Účast interventů byla $\mathrm{v}$ tomto systému dobrovolná. Změna nastala v roce 2016 s př́ichodem Pokynu policejního prezidenta č. 231/2016, o psychologických službách. Tímto pokynem tedy vznikl i systém kolegiální podpory (peer support). Zřízení systému kolegiální podpory je pokusem o zachování a zároveň rozšíření principu, který již byl přítomen u PIP, tedy principu nezištné, dobrovolné a vzájemné psychické podpory zaměstnanců/policistů (Voska, 2017).

Každý kraj má svého koordinátora kolegiální podpory. Koordinátorem systému kolegiální podpory je psycholog nebo poskytovatel kolegiální podpory jmenovaný ředitelem krajského ředitelství policie. Nejen krajská ředitelství, ale také útvary s celorepublikovou působností mohou mít svůj tým kolegiální podpory. Lektorem systému kolegiální podpory se může stát pouze psycholog, který po proškolení oddělením vedoucího psychologa Policejního prezidia ČR obdrží osvědčení o absolvování. Poté se stává zodpovědným za odbornou úroveň školení a průběžné vzdělávání poskytovatelů kolegiální podpory v kraji, kde působí. Dále rovněž zajišt'uje poskytovatelům kolegiální podpory psychologickou péči formou supervize. Systém má spíše preventivní charakter a vychází z předpokladů, že nikdo nemá lepší přehled o situaci, která na oddělení je, než člověk, který na něm působí. Není cílem vyškolit poskytovatele, kteří budou nahrazovat psychologické poradenství, nýbrž motivované, pozitivně naladěné kolegy, kteří v týmu mají přirozený respekt ostatních. Očekává se, že odbornou pomoc budou zprostřredkovávat. Jedná se o mladý program, který se neustále rozvíjí, a je zde stále několik oblastí, které je potřeba prohloubit či vymezit (např. výběr poskytovatelů kolegiální podpory, práva a povinnosti poskytovatelů, role psychologů v rámci systému kolegiální podpory, duchovní podpora, propagace programu). 
Třebaže praxe kolegiální podpory existuje již několik desetiletí, v oblasti empirického výzkumu zatím nebylo mnoho prokázáno (Grauwiler, 2008). Důvodem pro to je nemožnost zajistit dostatečnou př́snost při využití metod tradičního experimentu (tedy randomizované dělení experimentálních skupin), v případě, kdy zkoumáme službu $\mathrm{v}$ reálném světě, která je dobrovolná a zároveň založená na důvěře a osobních vazbách. Takto postavené výzkumy totiž jdou proti filozofii kolegiální podpory a místo vytváření důvěry navozují atmosféru výslechu (Resnick \& Rosenheck, 2008). Obecně tedy chybí přímý důkaz o efektivitě či přínosu programů kolegiální podpory.

\section{Cíle výzkumu}

Výzkumným cílem bylo získat zpětnou vazbu od poskytovatelů kolegiální podpory a zmapovat současnou situaci a praxi zavedení kolegiální podpory v České republice. Této oblasti dosud nebyla věnována žádná pozornost, třebaže systém v rámci Policie České republiky byl oficiálně zaveden v roce 2016. Na základě studia zahraniční literatury, zjištění a popsání stavu současné české praxe byly vymezeny tři okruhy, z nichž vycházejí výzkumné otázky.

\section{Role policistů coby poskytovatelů kolegiální podpory}

- VO(1a): ,,Jaké motivy vedou policisty $k$ tomu stát se poskytovateli kolegiální podpory?"

- $\quad \mathrm{VO}(1 \mathrm{~b})$ : „Jakým způsobem si poskytovatelé kolegiální podpory nastavují osobní hranice?"

- VO(1c): ,, Co považuji poskytovatelé kolegiální podpory na své roli za pozitivní a co za negativni?"

\section{Postavení kolegiální podpory v rámci policejní kultury}

- $\quad \mathrm{VO}(2 \mathrm{a})$ : ,, Jak se změnila atmosféra v týmu/oddělení po zavedeni kolegiálni podpory?"

○ $\quad \mathrm{VO}(2 \mathrm{~b})$ : , Jaké jsou bariéry v poskytováni kolegiální podpory?“

\section{III.Trénink a rozvoj dovedností}

- $\operatorname{VO}(3 \mathrm{a}):$, ,Jaké dovednosti či ziskané informace ze školení nejvíce v praxi poskytovatelé kolegiální podpory využivají?"

- $\quad \mathrm{VO}(3 \mathrm{~b})$ : „Jaké oblasti či dovednosti by poskytovatelé kolegiální podpory potřebovali prohloubit či je více a častěji procvičovat?" 
Jelikož se jedná o prvotní výzkumnou sondu do oblasti systému kolegiální podpory Police ČR, byl zvolen kvalitativní př́stup sběru dat. Metoda staví na přirozených podmínkách a vztazích, proto požadavek na univerzálnost a standardizaci je považován za nepřirozený zásah (Miovský, 2006). Nejinak tomu bylo i v tomto výzkumu. Třebaže respondenti byli omezeni předem zadanými okruhy otázek, byl jim dán dost široký prostor na to, aby témata mohli volně rozvinout a tím i dát prostor novým tématům či podnětům, které by jinak zůstaly skryty.

\section{Výzkumný soubor}

Výzkumný soubor tvořilo celkem 9 respondentů, policistů, kteří působí v rámci Středočeského kraje jako jedni z prvních poskytovatelů kolegiální podpory. To znamená, že prošli školením kolegiální podpory ještě před vydáním Pokynu policejního prezidenta č. 231/2016 o psychologických službách či krátce po jeho vydání. Středočeský kraj byl prvním krajem, který zavedl systém kolegiální podpory ještě před vydáním pokynu, a to v roce 2015. Výzkumný soubor je tedy tvořen těmi, kteří se do týmu kolegiální podpory přidali mezi prvními a fungují v něm dodnes. Důvodem tohoto výběru byla úvaha, že zhruba tř́letá praxe respondentů zaručí relevantnější výpovědní hodnotu, než těch, kteří v systému kolegiální podpoře působí krátce. Počet respondentů se ustanovil na čísle devět, jelikož se toto číslo ukázalo jako dostatečně velké z hlediska teoretického nasycení vzorku. Od šestého respondenta se odpovědi již začaly z větší části opakovat. Délka rozhovoru se pohybovala v rozmezí 40 minut až 1 hodiny.

Pro základní deskriptivní údaje (tab. 1) byl zjišt'ován věk respondentů, délka jejich působení u Policie ČR, pracovní zařazení, pohlaví. Pro lepší přehlednost jsou následující údaje uvedeny v tabulce níže. Z důvodu zachování anonymity jsou útvary, kde respondenti pracují, zevšeobecněny.

Tab. 1 Deskriptivní údaje respondetů

\begin{tabular}{|c|c|c|c|c|}
\hline & Pohlaví & Věk & $\begin{array}{l}\text { Počet let } \\
\text { u PČR }\end{array}$ & Zařazení \\
\hline Respondent č. 1 & muž & 32 & 9 & Služba pořádkové policie \\
\hline Respondent č. 2 & žena & 42 & 15 & Služba pořádkové policie \\
\hline Respondent č. 3 & žena & 43 & 20 & Služba cizinecké policie \\
\hline Respondent č. 4 & žena & 43 & 10 & $\begin{array}{c}\text { Služba kriminální policie } \\
\text { a vyšetř́ování }\end{array}$ \\
\hline Respondent č. 5 & žena & 48 & 16 & $\begin{array}{c}\text { Služba kriminální policie } \\
\text { a vyšetř́ování }\end{array}$ \\
\hline Respondent č. 6 & žena & 43 & 6 & Služba dopravní policie \\
\hline Respondent č. 7 & žena & 46 & 16 & $\begin{array}{c}\text { Služba kriminální policie } \\
\text { a vyšetřování }\end{array}$ \\
\hline Respondent č. 8 & žena & 39 & 18 & $\begin{array}{c}\text { Krajské ředitelství policie } \\
\text { Stř̌edočeského kraje }\end{array}$ \\
\hline Respondent č. 9 & Muž & 51 & 30 & $\begin{array}{l}\text { Krajské ředitelství policie } \\
\text { Stř̌edočeského kraje }\end{array}$ \\
\hline
\end{tabular}




\section{Metoda vyhodnocování a interpretace dat}

Výsledná data (přepisy jednotlivých rozhovorů) byla zpracována metodou vytváření trsů. Princip této metody totiž umožňuje seskupovat a konceptualizovat určité výroky do skupin (trsů), které vznikají na základě vzájemného překryvu (podobnosti). Na základě tohoto procesu vznikají obecnější, induktivně zformované kategorie, jejichž společným znakem je např. tematický překryv, to znamená, že ve výrocích osob jsou vyhledávány takové pasáže, které se týkají jednoho úzce ohraničeného tématu (Miovský, 2006).

Výsledná analýza výpovědí ukázala vznik 3 úrovní trsů. První úroveň již byla vymezena stanovením třech okruhů výzkumných otázek navazujících na literárně-přehledovou část. Druhá úroveň tvoří konkrétní výpovědi respondentů na předem vymezený okruh otázek. Jelikož se ukázalo, že druhá úroveň by byla stále hrubým zevšeobecněním výpovědí, byla zavedena i třetí úroveň, která popisuje a rozděluje další podoblasti výpovědí respondentů do konkrétnějších významových celků. K identifikaci a popisu trsů druhé a třetí úrovně bylo využito principu otevřeného kódování, tedy přiřazování označení jednotlivým nalezeným tématům (Hendl, 2005).

Při analýze výpovědí nebylo po pečlivém uvážení využito žádného programu specializujícího se na analýzu kvalitativních dat (např. ATLAS). Důvodů bylo několik. Jednak již byl dopředu poměrně přesně vymezen okruh otázek (témata rozhovorů), tudíž se ve výsledných transkripcích dobře tematicky orientovalo a nebylo zapotřebí složitě hledat jednotlivé významové celky. $\mathrm{K}$ tomu přispíval i nižší počet respondentů a poměrně brzké teoretické nasycení vzorku. Jelikož se jednalo o deskriptivní kvalitativní analýzu, nebylo zapotřebí hledat hlubší vztahy mezi jednotlivými trsy, a proto se ukázalo jako vhodnější ruční zpracování texti̊. V neposlední řadě byla výhodou ručního zpracování také skutečnost, že jazyk počítačového softwaru se může lišit od jazyka výzkumníka, a proto upravovat program pro každý dílčí krok analýzy zvlášt' může být v konečném důsledku pracnější a zdlouhavější (Yin, 2011).

\section{Výsledky}

Text je doplněn o některé $\mathrm{z}$ výroků respondentů $(\mathrm{R} 1, \mathrm{R} 2, \ldots)$. Ty byly vybírány tak, aby svým obsahem dokreslovaly realitu jednotlivých oblastí.

\section{Role poskytovatele kolegiální podpory}

VO(la): Motivace

Respondenti se shodují, že tím hlavním motivem je pomoc kolegům snášet a vyrovnávat se $\mathrm{s}$ nároky policejní práce, zájem o ně a dělat mimo hlavní náplň práce ještě něco navíc. Práce $\mathrm{s}$ lidmi je jim blízká a baví je. Současně dalším důvodem pro přihlášení do programu byla možnost vzdělání, uplatnění dovedností z předchozí praxe, využití poznatků v dalším studiu, zlepšení komunikace s lidmi a hledání lepšího porozumění sama sobě.

R8: „,...bude dobré se neustále v tom rozvíjet a zjištovat nový informace a naučit se i víc s těma lidma fungovat, mluvit..."

VO(1b): Osobni hranice

Respondenti se k tématu nastavení osobních hranic vyjadřovali ve třech rovinách. V první rovině vnímali osobní hranice $\mathrm{v}$ souvislosti s svou rolí poskytovatele kolegiální podpory. Respondenti prakticky nevnímají rozdíl, mluví-li s kolegy jako poskytovatelé či jako kolegové. 
Rozhovory jsou tak přirozené, že samotní kolegové nevědí, v jaké roli se s nimi dotyčný poskytovatel mluví. Dochází tedy k prolínání rolí, v nichž poskytovatel na oddělení či v týmu vystupuje. Techniky, které se dozvěděli na školení, si natolik zvnitřní, že je automaticky využívají i v rozhovorech, kde jako poskytovatelé nevystupují.

R5: „,...já si myslím, že si to ti lidi vůbec neuvědomujou, že to dělám, i na těch obvodech. “

Druhá rovina se vztahuje k oblasti nastavení osobních hranic jako ochrany soukromí, a to zejména v ochotě dávání soukromého telefonního čísla. Pro poskytovatele se ukázalo jako důležité dokázat oddělit kolegiální podporu od svého soukromí. Došlo-li k narušení soukromí nočními telefonáty, uměli si vytyčit hranici tím, že dotyčnému vysvětlili, do jaké míry jsou jim ochotni pomoci a kde tato ochota má své hranice.

R2: „Nedala jsem soukromé, nechci, aby mi lidé volali večer, protože jak řikáte, znám své hranice, pracuju tady dlouho a nechci si to tahat domü. "

Poslední oblast, kterou respondenti zmínili, se týkala nastavení osobních hranic jako ochrany duševního zdraví. Ukázalo se, že poskytovatelé nemohou pracovat s kolegy, jejichž problém se současně dotýká i problému, který právě řeší samotní poskytovatelé. V rámci zachování psychické pohody bud' tyto kolegy odkážou na jinou pomoc, nebo se snaží s nimi toto téma př́liš do hloubky nerozebírat. Necítí se na kompetentní a zároveň ví, že by nedokázali být nestranní.

\section{VO(lc): Prínos role}

Díky roli poskytovatele kolegiální podpory měli př́iležitost k velkému osobnímu seberozvoji. Ten respondenti vnímají jako velké plus, které jim role poskytovatele přinesla. Zejména se jedná o hlubší sebepoznání a sebeporozumění, zvláště v situacích, kterým v minulosti čelili a porozuměli jim až posléze. Role jim přinesla větší životní nadhled, rozšíření obzorů a pocit bezpečí v tom smyslu, že na problémy ostatních nejsou sami, ale mají podporu psychologů. Vedle seberozvoje je pro poskytovatele důležitý taky pocit smysluplnosti jejich působení v rámci týmu či oddělení. Pozitivním přínosem je pro ně zvědomení jejich užitečnosti, uspokojení a pocitu zadostiučinění, v tom smyslu, že jejich rolí je hlavně nezištná pomoc a opora kolegů. V neposlední řadě je př́nosem i budování nových vztahů, tedy rozšíření okruhu přátel a jejich pravidelné setkávání v rámci supervizí či seminářů. Negativní stránka role poskytovatele nebyla $\mathrm{v}$ rámci rozhovorů tolik zmiňována a rozvíjena. Jednotlivě byla zmíněna větší psychická zátěž a ztráta iluzí ve smyslu, že existují problémy, které člověk nedokáže vyřšsit.

R2: „, Tak vzalo mi to trošičku takovou tu naivitu, jakože všechno se dá vyřešit, protože prostě tam zjistite, když vás holky proškolujou, že jsou věci, které nemůžete vyřešit, to je jedna z věcí, těch záporných." 


\section{Systém kolegiální podpory a policejní kultura}

\section{VO(2a): Atmosféra v týmu}

Smyslem výzkumné otázky bylo zachytit, jestli se změnila atmosféra v týmu poté, co v něm začal poskytovatel vystupovat ve své oficiální roli. Po zavedení kolegiální podpory prakticky nenastala žádná změna atmosféry $v$ týmu, a když už byla respondenty zmíněna, tak spíše změna v negativním slova smyslu, a to tak, že ztratili důvěru lidí, kteří za nimi dříve chodili, či okolí zůstalo stejně pořád nedůvěřivé, nebo dotyčnému poskytovateli začali atmosféru na pracovišti ještě více zneprŕíjemňovat. Pouze v jednom př́ipadě byl zmíněn pozitivní dopad, nicméně ten byl navázán na životní př́iběh konkrétního poskytovatele.

\section{VO(2b): Bariéry}

Rozhovory s poskytovateli přinesly zjištění, že bariér, které stojí v cestě rozvoji kolegiální podpory, je stále hodně. Nejvíce zmiňovaná byla bariéra strachu ze ztráty zaměstnání. Respondenti se napříč svými výpověd'mi shodli na tom, že u policie neustále převládá přesvědčení, že mít problém ve smyslu náročnějšího životního období, ztráty blízké osoby, prožití traumatické události znamená pro policisty škatulku vážného psychického problému, návštěvu psychologa, následný přezkum psychické způsobilosti a možné propuštění. To souvisí s nedůvěrou jednak vůči psychologům, jednak vůči samotným poskytovatelům. Policisté si své soukromí chrání a nechtějí, aby o nich ostatní věděli, že mají problémy. Proto nedůvěřují, jelikož mají obavu, že tyto informace budou sděleny nadřízenému, a rozjede se výše zmíněné kolo. Strach a nedůvěra jdou ruku v ruce s převládajícím mýtem nezlomného policisty, který nemá žádné, natož osobní problémy, a ukázat či přiznat je, by byl projev slabosti.

\section{R3: „,...tady je to takový fakt, tabu, tady jenom práce a nedej bože, že by tady někdo} připustil, že by mohl mít jako policista soukromý problémy. “”

Co dále zabraňuje rozvinutí kolegiální podpory, je role nadřízeného, která jde ruku v ruce s nedostatkem informací o kolegiální podpoře. V okamžiku, kdy nadřízený nerozumí smyslu kolegiální podpory, vnímá ji jako něco nesmyslného, zbytečného, co policisty odvádí od jejich náplně práce. Nechtějí je pouštět na školení, netolerují jejich činnost. Tento fakt naráží na skutečnost, že vedoucí neví, co jim kolegiální podpora může v rámci oddělení přinést. Je to jedna z věcí, která splyne ve vydaných rozkazech. Respondenti zmiňují jako další přidruženou reakci k odmítnutí kolegiální podpory, a to zlehčení, výsměch, znevážení a bagatelizování této činnosti.

\section{Trénink a rozvoj dovedností}

VO(3a): Prínos školení

Největším překvapením a přínosem pro většinu respondentů bylo po absolvování vstupního školení prožití pocitu vlastního tzv. odbřemenění v rámci role, kterou at' už v rámci týmu vykonávali nebo se ji chystali vykonávat, a to ve dvou rovinách (odbřemenění v přenesení zodpovědnosti a odbřemenění ve smyslu podpory). Tou nejvýraznější z nich byla rovina pocitu vlastní zodpovědnosti na řešení problému kolegy. Pro mnoho respondentů bylo velmi úlevné zjištění, že oni nejsou zodpovědní za to, aby vyřešili problém kolegy. Zároveň si zde uvědomili častou chybu, a to, že dříve přirozeně všem radili, jelikož své řešení a své hledisko 
považovali za to správné. Další rovinou byla rovina pocitu, že na řešení problému nejsou sami, tudíž že se kdykoliv s čímkoliv mohou obrátit jednak na psychology, jednak na další poskytovatele.

R2: „, ...tak najednou na to máte návod, najednou vite, že když máte stres a bolí vás srdce, tak nemáte infarkt, ale už víte z toho školení, že to je stahování cév, a že to jsou příznaky. “

\section{VO(3b): Nedostatky školení}

Systém školení a seminářu se ukázal jako veskrze komplexně vystavěný. Respondenti neměli výhrady k tomu, že by jim v rámci školení něco zásadně chybělo, co by jim následně ulehčilo praxi poskytovatele. Pouze dva aspekty byly zmíněny, a to že jednomu respondentovi chyběly informace již při vstupním školení o externí psychosociální síti, tedy kontakty kam odkazovat, má-li klient specifický problém týkající se rodiny, dětí, finančních problémů apod. Druhý respondent by uvítal $\mathrm{v}$ rámci seminářů zaměřených na konkrétní téma jasnější vymezení kompetencí, tedy do jaké míry určitý problém může řešit on sám a do jaké míry už klienta s konkrétním problémem musí odkázat na odbornou péči (např. u závislostí).

\section{Další oblasti}

Výše zmíněné kapitoly popisovaly tři trsy první úrovně, které byly předem vymezeny jako tři okruhy výzkumných otázek. Následně byly představeny a popsány trsy druhé úrovně, a to na základě výpovědí respondentů na určené výzkumné otázky. Nyní se pohybujeme v rámci trsu druhé úrovně, tedy bude se jednat o oblasti, které respondenti zmínili souběžně s odpověd'mi na výzkumné otázky. Tyto trsy vznikly tak, že na základě identifikace opakujících se témat respondentů jim byl přidělen nadřazený pojem. Nicméně se posléze ukázalo, že i některé tyto tematicky vymezené výpovědi mají ještě další vnitřní členění, proto bylo znovu využito trsu třetího stupně, coby způsobu diverzifikace výpovědí, a to jednak z důvodu lepší přehlednosti a jednak zamezení ztráty specifických podoblastí.

\section{Výběr poskytovatelů}

Výběr poskytovatelů je prozatím v ČR oblastí, která nemá systematičtější ukotvení. Na základě jednotlivých výpovědí respondentů není zrrejmé, zda je výběr zájemců nutný a pokud ano, jakou by selekce zájemců o kolegiální podporu měla mít podobu. Z výpovědí vyplývá, že respondenti výběr ponechávají odborníkům a spoléhají na jejich expertní znalost. I přes to, že zatím není výběr formálně vymezen, kolegiální podpora ve Středočeském kraji je zavedena, v týmech funguje a rozvíjí se.

R2: „,...tím, že děláte různý dotazníčky, různý scénky, oni vás pozorujou, ony se ptaj, ony jakoby to co si myslím, tak jak jezdíme dneska na soustředěni a jsou tam lidi se mnou, tak jsou to všechno lidi na svých mistech. Jestli je tam jeden, dva, který ne ... [...] Holky to prostě maj $v$ sobě... jakoby poznaj to. Jsou tam prece ony... je tam verbální a neverbální komunikace, ta tam je a ten člověk se prozradí. “ 


\section{Osobnost poskytovatele}

Většinou rozhovory začínaly otázkou na motivaci, co vedlo poskytovatele se do kolegiální podpory přihlásit a vedle oblasti motivace (viz výše) respondenti zmiňovali své osobnostní přednastavení pro tuto roli. Častým pojmem, který se v souvislosti se vstupem do týmu kolegiální podpory objevoval, byl pojem vrba. Poskytovatelé, kteří vstupovali jako první do týmu kolegiální podpory, již dříve tuto funkci v rámci svého týmu tak nějak laicky vykonávali, aniž by tuto činnost měli nějak formálně pojmenovanou. Vždy byli jakousi vrbou, za kterou si kolegové přišli popovídat a zároveň oni sami měli o lidi a o to, jak se jim daří, zájem. Veškerý kontakt byl přirozený a vyplýval z charakteru práce, který poskytovatelé měli.

\section{R7: „...ještě predtím než jsem sloužila u tohoto týmu, tak za mnou chodili někteři kolegové, ne nějak jako na pokec, svěrit se s nějakýma osobníma problémama. “}

\section{Kontakt}

V průběhu rozhovoru se respondenti dotkli i oblasti, která popisuje, jakým způsobem dochází k poskytování kolegiální podpory $\mathrm{v}$ jejich každodenní praxi. Proto tato oblast byla pojmenována Kontakt. V rámci výpovědí byly identifikovány tři roviny, které s kontaktem v každodenní praxi souvisí. První z nich je tzv. známost, tedy pojem popisující to, do jaké míry poskytovatelé své klienty znají, druhá je frekvence, tedy jak často se poskytovatelé s klienty stýkají a třetí je způsob oslovení, tedy jak dochází ke styku či propojení poskytovatele s klientem.

R7: „Bud’ telefonicky, a nebo jen tak prijidou mezi řečí, že jdou okolo, tak jak se máš, přijdou, sednou si, a tak no...[...] to ani nemá jako nějaký oficiální nějaký jako, že bychom se domluvili a řekli, tak a ted' budeme néco... jakoby konzultovat nebo to.. je to takový jako prirozený."

\section{Podpora}

Téma podpory se objevilo ve všech rozhovorech, každý respondent se jej v nějaké rovině dotkl. Podporu respondenti zmiňovali jako velmi důležitý opěrný bod z hlediska jejich role a poskytování pomoci. Jak již bylo zmíněno výše, poznání, že na pomoc nejsou poskytovatelé sami, bylo úlevné. V této části proto budou uvedeny na základě výpovědí respondentů, jednotlivé roviny podpory, s nimiž přijde poskytovatel do kontaktu a které jsou pro jeho roli velmi potřebné. Základní úroveň vzájemné podpory tvoří obousměrná podpora poskytovatelů (poskytovatel vs. poskytovatel). Na této úrovni se radí ohledně některých postupů u klientů, a to, jak s nimi dál komunikovat, jak situaci dál řešit apod. Další úrovní je podpora poskytovatele u psychologa (poskytovatel vs. psycholog), a to zejména a u těžších případů. U psychologa může také nalézt oporu $\mathrm{v}$ tom, že $\mathrm{v}$ př́ípadě, který nikam dál nevede, už udělal maximum. Někteří poskytovatelé se na psychology obrací automaticky, aniž by nejdřive vyhledali podporu v rámci ostatních poskytovatelů. Podpora nemusí být pouze uvnitř organizace, ale poskytovatelé mají možnost odkázat své klienty i mimo oblast policejní organizace (poskytovatel vs. externí psychosociální sít'), a to zejména v případech, kdy se jedná 
o specifické problémy (např. děti, finanční problémy, právní problémy, péče o seniory). Všechny tyto možnosti se nabízí jako opora při poskytování pomoci. Trochu mimo tuto oblast stojí ještě podpora vedoucího jako velmi důležitá součást celého systému kolegiální podpory, a to zejména v uvolňování poskytovatelů na školení, supervize a semináře.

\section{Kompetence}

V rámci poskytování podpory na úrovni poskytovatel vs. psycholog se zároveň respondenti dostávali k tématu, kdy problém klienta mohou řešit sami a kdy je potřeba se již obrátit na psychologa, tedy kde končí jejich kompetence a začíná nastupovat role psychologa. O vymezení kompetencí se během rozhovoru zmínili tři respondenti. U všech je patrné, že si jsou vědomi svých hranic, jednak intuitivně, jednak jsou základní témata, při nichž je nutné vyhledat další psychickou pomoc, představena v rámci vstupního školení. Jeden respondent se o nedostatečném vymezení kompetencí zmínil z hlediska nedostatků vstupních školení (viz výše). Nicméně praxe však ukazuje, že sami poskytovatelé za nějaký čas v kontaktu s klientem sami poznají, kdy je potřeba odkázat dotyčného k odbornější pomoci. Spoléhají na svůj osobní pocit.

R1: ,...když už vím, že co jsme spolu probrali a jako že to nikam moc nevede, tak jsem schopnej ho odkázat normálně na psycholožku a ty už s ním pak dále pracují.“

\section{Psychohygiena}

$\mathrm{U}$ některých respondentů se $\mathrm{v}$ rámci rozhovoru objevilo i téma psychohygieny. $\mathrm{S}$ ní se poskytovatelé seznamují již v rámci úvodního školení. $Z$ hlediska výpovědí respondentů lze jejich způsob psychohygieny rozdělit na dvě oblasti. Někteří respondenti raději vyhledají přirozenou sociální sít', u které se vypovídají (s kamarády na pivo, školení), jeden respondent uvedl ruční, fyzické práce.

\section{Mlčenlivost}

Mlčenlivost a věci s ní spojené bylo časté respondenty zmíněné téma. Z hlediska správného fungování systému kolegiální podpory se jedná o zásadní věc, která by měla být podchycena již u zrodu systému v rámci organizační kultury. Na odpovědi respondentů lze pohlížet ze dvou úhlů pohledů. Jednak se jedná o zachycení úrovně kodifikace mlčenlivosti, jednak rozšiřrení povědomí o jejích zásadách. Tyto dva úhly pohledu se odrážely ve většině odpovědí. Někteří respondenti reflektují křehkost mlčenlivosti, na které je zároveň však celý systém kolegiální podpory vystaven. Dále zmiňují absenci trestu za její použití a zároveň absenci kodexu, který by tuto mlčenlivost kodifikoval a zformalizoval.

R2: „Oni se 30x zeptaj a neřekneš to nikomu, že ne, tak tam jim to zopakuju, že tam je mlčenlivost a pokud bych to někomu řekla, tak že prostě letím, že to je prostě problém, ale myslím si, že kodexy máme každý svoje v sobě, protože tuto jakoby nadpráci může dělat jenom člověk, který má jenom nějaký hodnoty, svoje hodnoty. “ 


\section{Limity kolegiální podpory}

Dva respondenti narazili na limity kolegiální podpory, tedy na témata, která když se u klientů objeví, nemohou je ze své pozice nijak vyřešit, ani si pomoci odkázáním klienta na jinou péči. Konkrétně se jedná o téma vnitřního nastavení organizace, a to konkrétně o nespravedlivé zacházení ze strany vedoucího, frustrace z pracovní náplně a nesmyslnosti požadavků, které musí v rámci výkonu profese plnit.

\section{Propagace}

Pojem propagace v sobě zahrnuje dvě oblasti, v jejichž rámci se respondenti často svými výpověd'mi pohybovali. Do tohoto pojmu bylo zahrnuto téma uvedení poskytovatele $\mathbf{v}$ jeho nové roli do týmu. V mnoha výpovědích se objevilo, jakým způsobem byli po absolvování školení a nabytí nové role poskytovatele kolegiální podpory představeni týmu či kolektivu, ve kterém se pracovně pohybovali. Odpovědi respondentů se různily, nicméně nejčastěji zmiňovali, že představení bylo zcela formální, tedy že proběhlo Esiářem ${ }^{2}$ a posléze se na intranetu objevilo jejich jméno s kontaktem. Další možností se ukázal jev, kdy se tato informace samovolně roznese po oddělení. Někteří respondenti nebyli představeni vůbec. Druhé velké téma bylo označeno jako informovanost, a to ve smyslu existence programu kolegiální podpory, ujasnění jejího smyslu a normalizace služeb poskytovatelů. Respondenti zmiňovali komplikovanou dostupnost informací a vágní popis služeb (i psychologických na intranetu). $\mathrm{V}$ některých $\mathrm{z}$ výpovědí byl rovněž apel na samotné psychology, aby v rámci své agendy měli i osvětovou činnost ve vztahu $\mathrm{k}$ jejich roli $\mathrm{v}$ rámci sboru a také zejména směrem $\mathrm{k}$ vedení nejenom krajů, ale také alespoň $v$ rámci územních obvodů. Jeden respondent uvedl, že kolegiální podpora by měla být vedení prezentována jako preventivní program udržení psychické pohody na pracovišti. Jako funkční se ukázala informovanost v rámci zpř́stupnění seminářu pro širší policejní veřejnost a ne pouze pro samotné poskytovatele. Tím se rovněž rozšírí myšlenka kolegiální podpory mezi účastníky dál, a zároveň zde může dojít propojení nějakého „aha zážitku“ ze semináře dohromady s informací o účelu kolegiální podpory.

\footnotetext{
${ }^{2}$ Elektronická sbírka interních aktů řízení (dále ESIÁŘ), který obsahuje veškeré závazné pokyny a metodiky týkající se plnění úkolů a činností PČR.
} 


\section{CPsychologie

\section{Shrnutí}

Pro lepší orientaci v úrovních jednotlivých trsů je níže uvedena přehledové tabulky (tab. 2, tab. 3) s výsledky výpovědí respondentů.

Tab. 2 Výzkumné otázky

\begin{tabular}{|c|c|c|c|c|c|c|c|}
\hline & \multicolumn{7}{|c|}{ Výzkumné otázky } \\
\hline $\begin{array}{l}\text { Trs první } \\
\text { úrovně }\end{array}$ & \multicolumn{3}{|c|}{$\begin{array}{l}\text { I } \\
\text { Role policistů coby poskytovatelů } \\
\text { kolegiální podpory }\end{array}$} & \multicolumn{2}{|c|}{$\begin{array}{l}\text { II } \\
\text { Postavení kolegiální podpory v rámci } \\
\text { policejní kultury }\end{array}$} & \multicolumn{2}{|c|}{ III } \\
\hline $\begin{array}{l}\text { Trs druhé } \\
\text { úrovně }\end{array}$ & $\begin{array}{l}\mathrm{VO}(1 \mathrm{a}) \\
\text { Motivace }\end{array}$ & $\begin{array}{c}\text { VO }(1 b) \\
\text { Osobní hranice }\end{array}$ & $\begin{array}{l}\text { VO }(1 \mathrm{c}) \\
\text { Př́nos role }\end{array}$ & $\begin{array}{c}\text { VO (2a) } \\
\text { Atmosféra v týmu }\end{array}$ & $\begin{array}{l}\text { VO (2b) } \\
\text { Bariéry }\end{array}$ & $\begin{array}{c}\text { VO (3a) } \\
\text { Přínos školení }\end{array}$ & $\begin{array}{c}\text { VO (3b) } \\
\text { Nedostatky školení }\end{array}$ \\
\hline $\begin{array}{l}\text { Trs třetí } \\
\text { úrovně }\end{array}$ & $\begin{array}{l}\text { pomoc } \\
\text { kolegům, } \\
\text { vzdělání }\end{array}$ & $\begin{array}{l}\text { role poskytovatele, } \\
\text { ochrana soukromí, } \\
\text { ochrana duševního } \\
\text { zdraví }\end{array}$ & $\begin{array}{c}\text { osobní } \\
\text { seberozvoj, } \\
\text { pocit } \\
\text { smysluplnosti, } \\
\text { budování } \\
\text { nových vztahů }\end{array}$ & žádná změna & $\begin{array}{l}\text { strach ze ztráty } \\
\text { zaměstnání, } \\
\text { nedůvěra, mýtus } \\
\text { nezlomného policisty, } \\
\text { role nadřízeného, } \\
\text { nedostatek informací, } \\
\text { zlehčení }\end{array}$ & $\begin{array}{l}\text { odbřemenění v přenesení } \\
\text { zodpovědnosti, } \\
\text { odbřemenění ve smyslu } \\
\text { podpory, technika } \\
\text { efektivního naslouchání, } \\
\text { technika kladení otázek, } \\
\text { informační hodnota }\end{array}$ & $\begin{array}{l}\text { externí } \\
\text { psychosociální sít', } \\
\text { vymezení kompetencí }\end{array}$ \\
\hline
\end{tabular}




\section{(D) psychologie

Tab. 3 Další oblasti

\begin{tabular}{|c|c|c|c|c|c|c|c|c|c|}
\hline Trs první & \multicolumn{9}{|c|}{ Další oblasti } \\
\hline $\begin{array}{l}\text { Trs druhé } \\
\text { úrovně }\end{array}$ & $\begin{array}{c}\text { Výběr } \\
\text { poskytovatele }\end{array}$ & $\begin{array}{c}\text { Osobnost } \\
\text { poskytovatele }\end{array}$ & Kontakt & Podpora & Kompetence & Psychohygiena & Mlčenlivost & Limity KP & Propagace \\
\hline $\begin{array}{l}\text { Trs třetí } \\
\text { úrovně }\end{array}$ & $\begin{array}{l}\text { expertní } \\
\text { znalost }\end{array}$ & vrba & $\begin{array}{c}\text { známost, } \\
\text { frekvence, } \\
\text { způsob } \\
\text { oslovení }\end{array}$ & $\begin{array}{l}\text { poskytovatel vs. } \\
\text { poskytovatel, } \\
\text { poskytovatel vs. } \\
\text { psycholog, } \\
\text { poskytovatel vs. } \\
\text { externí psychosociální } \\
\text { sít', podpora } \\
\text { vedoucího }\end{array}$ & osobní pocit & $\begin{array}{l}\text { sociální sít', } \\
\text { fyzická práce }\end{array}$ & $\begin{array}{l}\text { úroveň } \\
\text { kodifikace, } \\
\text { povědomí } \\
\text { o jejích } \\
\text { zásadách }\end{array}$ & $\begin{array}{c}\text { vnitřní } \\
\text { nastavení } \\
\text { organizace }\end{array}$ & $\begin{array}{l}\text { uvedení } \\
\text { poskytovatele } \\
\text { v jeho nové } \\
\text { roli do týmu, } \\
\text { informovanost }\end{array}$ \\
\hline
\end{tabular}




\section{Diskuze}

Cílem výzkumné studie bylo popsat systém kolegiální podpory Policie ČR, a to z hlediska tří předem vymezených oblastí. Výsledky rozhovorů s poskytovateli kolegiální podpory přinesly následující odpovědi na výzkumné otázky. Motivací, proč se policisté do týmu kolegiální podpory přihlásili, bylo, že chtěli navíc pomáhat kolegům a toužili po dalším vzdělávání. $S$ délkou praxe přestávají rozlišovat, zda mluví se svými přáteli jako peer či jako kamarád. Tyto hranice se jim stírají. Výzkum přinesl poznatek, že kolegiální podpora je něco, co lidé přirozeně dělají, jen se tomu začal dávat oficiální rámec. $Z$ výpovědí respondentů vyplynulo, že často ani nevnímají rozdíl mezi rolemi poskytovatele a kamaráda. Naopak v USA se tato praxe jeví jako běžná a jsou tedy i formálně oddělená a pojmenovaná jako podpora první a druhé úrovně (Digliani, 2015).

Poskytovatelé si umí vytyčit hranice $\mathrm{v}$ př́padě, kdy jim podpora začne až př́liš zasahovat do soukromého života a také se ukázalo (srov. Burger, 2012), že poskytovatelé neradi konzultují ty problémy, které současně řeší i ve svém osobním životě. Role poskytovatele jim přinesla osobní seberozvoj, pocit smysluplnosti a rozšíření okruhu známých. K bariérám, které brání v plném rozvoji kolegiální podpory, patří strach ze ztráty zaměstnání, v př́ípadě, že se odhalí, že policista tuto službu využívá a potažmo má psychické problémy, nedůvěra v poskytovatele, role nadřízeného, který jakýmkoliv způsobem brání rozvoj podpory, nedostatek informací o smyslu a účelu podpory a také její zlehčování. Z hlediska policejní kultury přinesl výzkum zjištění, že v některých ohledech nejsou rozdíly mezi policejní kulturou v ČR a zahraničí. Jak uvádějí zahraniční výzkumy, psychické onemocnění je stigmatizující (White, 2016) stejně jako náznak slabosti (Link a Phelan, 2001). Proto policisté při obtížích nevyhledávají odbornou pomoc (Alexander \& Walker, 1994). Nejinak tomu je v ČR, kdy ve sboru neustále převládá mýtus nezlomného policisty, jehož psychické problémy neexistují a ani nikdy neexistovaly.

Trénink a rozvoj dovedností v rámci vstupního školení je, co se týče obsahové stránky, podobný s americkým prostředím (Creamer, 2012). V obou př́ípadech je hlavní důraz kladen na efektivní naslouchání, rozvoj technik vedení rozhovoru, posouzení závažnosti problému a následné doporučení na odbornou pomoc. Co však přineslo poskytovatelům úvodní školení (vyplynulo z výsledků výzkumu), bylo poznání, že nemusí nést tíhu veškeré odpovědnosti v př́ípadě, že se jim kolega svěří, zároveň jim přineslo úlevu zjištění, že na řešení problému nejsou sami, ale mají podporu v sobě navzájem, psychologů či externí psychosociální sítě. V českou praxi není průběžné ověřovací přezkoušení, zda poskytovatel plní svou funkci tak, jak má (srov. Creamer, 2012). Lze tedy říci, že poskytovatelům školení pomohlo v tom pojmenovat a zvědomit si věci či procesy, které se lidem v životě dějí, a často proto, že si je neumí pojmenovat, tak se s nimi ani nedokáží psychicky vyrovnat.

V porovnání s českým současným stavem je i výběr poskytovatelů podpory v USA vysoce formalizovaný. Podle Diglianiho (2015) by uchazeči měli mít o roli zájem, vstupovat do ní s určitým závazkem a být důvěryhodný. Výsledky z českého prostředí ukázaly, že zahraniční formální kroky jsou u nás zastoupeny expertním posouzením psychologů, a to na základě pozorování jejich interakce v rámci vstupního školení. I tak má stále každý stejnou šanci stát se poskytovatelem. 
V zahraniční literatuře je poměrně jasně vymezena role poskytovatele v oblasti zachovávání mlčenlivosti, tedy jsou popsány prŕípady, kdy je poskytovatel povinen skutečnost nahlásit, byt' ani v tomto neexistuje konsenzus např́íč jednotlivými policejními odděleními (Creamer, 2012). V českém prostředí poskytovatelé nemají udělená nějaká výjimečná práva, proto pro ně platí stejná ohlašovací povinnost jako pro všechny ostatní občany. Ve výzkumu bylo téma mlčenlivosti spojeno se skutečností, že informace, které poskytovatel od klienta zjistí, neprozradí. Nyní zatím není žádný etický kodex, který by upravoval toto etické hledisko, a tak se každý poskytovatel spoléhá na své vnitřní morální hodnoty. Současně na rozdíl od USA (Creamer, 2012), nejsou stanoveny žádné sankce za porušení mlčenlivosti či jiné nevhodné chování, kterého by se poskytovatel mohl dopustit, a zároveň by klienta poškodilo.

Podpora a starost o duševní zdraví poskytovatelů je stejně jako v USA (srov. Creamer, 2012; Digliani, 2014), podchycena v českém prostředí. O tom, jak pečovat o své duševní zdraví, se poskytovatelé dozvědí již na vstupním školení. Výzkum ukázal, že je jim poměrně hodně nabízena a i silně doporučována podpora psychologů, ale také potřeba poskytovatelů se podporovat navzájem. Současně jsou v rámci doplňkových seminářů seznamováni s principy a projevy těch oblastí, které mají souvislost s duševním zdravím a udržováním psychické pohody.

Výzkum přinesl i nová témata, která v zahraničních zdrojích nejsou explicitně zmíněna, a to jednak proto, že je možná nepokládají za důležité, jednak že se může jednat o témata spjata se specifickým českým kulturním prostředím. Ukázalo se, že pro úspěšné rozšiřování myšlenky a principu kolegiální podpory je velmi důležitý způsob její propagace, který se odráží ve všeobecné větší informovanosti zejména vedoucích pracovníků, a to např́íklad prostřednictvím webových stránek či prezentací psychologů ve smyslu osvětové činnosti co je kolegiální podpora a co může vedoucím pracovníkům přinést. Rozhovory přinesly i poodkrytí oblasti limitů kolegiální podpory, kterou vnímali zejména v rámci vnitřního nastavení organizace. $\mathrm{V}$ průběhu vyprávění se respondenti dotkli i tématu kontaktu, tedy způsobů, jak jsou klienty oslovováni a o jaké typy kontaktů se jedná. Ukázalo se, že v tomto př́ípadě je vše zcela individuální, u některých poskytovatelů převažoval spíše jednorázový kontakt, u jiných opakovaný. Obecně se však shodli, že všechny klienty minimálně od vidění znali a že spíše spočívá aktivita na nich. Oni sami si musí více všímat těch, kteří by podporu potřebovali a sami je přirozeným způsobem oslovit. V neposlední řadě výzkum odhalil, že většina z respondentů má osobní přednastavení $\mathrm{k}$ tomu, že se jim lidé přirozeně svěřují. Oblast témat, $\mathrm{s}$ jakými se policisté obrací na poskytovatele, byla vynechána záměrně, jelikož se jedná o informace, které jsou každoročně statisticky zpracovávány a vyhodnocovány $\mathrm{v}$ rámci výroční zprávy psychologického pracoviště policejního prezidia.

Jako každý psychologický výzkum, tak i tato práce má svá omezení, která v konečném důsledku mohou zkreslit konečné výsledky. Autorka si je této skutečnosti vědoma, a proto uvádí ty nejvýznamnější z nich. Prvním významným limitem je již volba samotné metody kvalitativního př́stupu ke zkoumání systému kolegiální podpory. Výsledky tohoto výzkumu nelze nijak zevšeobecňovat. Jejich účelem je čtenářưm poskytnout prvotní vhled do systému kolegiální podpory Policie ČR. Z hlediska respondentů může zkreslovat výsledky skutečnost, že nebyla zachována homogenita respondentů, co se týče předchozí zkušenosti s poskytováním psychické pomoci. Ne pro všechny respondenty byla zkušenost se školením kolegiální podporou první. Někteří respondenti již v minulosti působili at' už v týmu PIP či týmu krizové intervence. 
Třebaže výběr respondentů byl založen na metodě záměrného výběru, bylo ve skutečnosti osloveno více poskytovatelů, než se jich ve skutečnosti k výzkumu přihlásilo. Proto mohou být výsledky zkresleny i samovýběrem, tedy nepř́znivým jevem, kdy se výzkumu účastní pouze ti lidé, kteří se účastnit chtějí.

Za další limit lze považovat zvolenou metodu pro analýzu datového souboru. V práci bylo využito deskriptivní analýzy, a to konkrétně metody vytváření trsů. Deskriptivní analýza totiž neumožňuje hlubší práci $\mathrm{s}$ daty a tak dochází $\mathrm{k}$ jejich mnohým ochuzením a omezením. Analytické nástroje skrývají velké množství práce $\mathrm{s}$ daty a dokáží tak $\mathrm{z}$ nich získat více validních informací, než jaké získáme pouhou deskripcí a klasifikací (Miovský, 2006). Nicméně již samotná metoda vytváření trsů by měla být zároveň i metodou, která validitu výzkumu kontroluje, jelikož je založena na principu ověřování a potvrzování (Miovský, 2006). Při postupu tvorby a přiřazování opakujících se výpovědí do jednotlivých úrovní trsů často docházelo k prolínání či navazování některých témat na sebe. Např́klad změna atmosféry v týmu úzce souvisí s propagací a bariérami, avšak výchozí metodou pro analýzu dat byla zvolena metoda deskriptivní, tudíž vztahy mezi jednotlivými trsy nebyly vyhledávány ani jim nebyly přisuzovány žádné vztahy. Proto přehledové tabulky a rozdělení trsů do úrovní a tematických celků může působit na první pohled uměle.

Samozřejmě nelze také neopomenout zkreslení způsobené rolí výzkumníka v procesu získávání dat. Výzkumník totiž může hrát roli tzv. ,,aktivního filtru“, který př́íjímá pouze to, co mu sedí do jeho rámce a naopak vytěsňuje to, co do něj „nesedí“ (Miovský, 2006). V tomto případě je navíc výzkumník nejenom v roli tazatele, ale i kolegy či „kontroly“ z policejního prezidia. Proto některé výpovědi respondentů mohou být až př́liš intimní, jelikož výzkumníka považují za kolegu, a tedy nemají vůči němu žádné zábrany. Naopak u některých respondentů může tato role způsobit, že se vůči němu spíše uzavřou z obavy, že se jedná o pracovníka z policejního prezidia, který by vedle toho mohl kontrolovat jejich činnost.

Proměnnou, která rovněž může zkreslit výsledky, je samotný výběr probandů z jednoho konkrétního kraje. Na to, jak probandi odpovídali, co považovali za důležité zmínit a naopak, o čem nemluvili, může mít vliv i to, jak je systém kolegiální podpory vnímán vedením kraje. Zda je jako celek přijímán pozitivně či zda je vnímán jako zátěž ve vazbě na uvolňování policistů ze služby (z důvodu podstavů). To rovněž může souviset i se situací, zda před systémem kolegiální podpory v kraji fungovala jiná forma psychické podpory (např. PIP). Mezi další proměnné lze uvažovat i samotnou velikost kraje, počet policistů, ale také demografické ukazatele kraje, jeho socioekonomickou úroveň či počet mimořádných událostí. I tento globálnější pohled může výsledky do jisté míry ovlivňovat.

Vedle specifik Středočeského kraje, co do jeho postavení v porovnání s ostatními kraji, se mohou určitého zkreslení dopustit i koordinátoři či lektoři z daného kraje, a to z hlediska jejich př́stupu a porozumění systému kolegiální podpory. To, jak kolegiální podpoře rozumí, zda ji hodnotí podobně či jakým způsobem její principy předávají, může poté ovlivňovat jednak samotné poskytovatele kolegiální podpory, jednak policisty, kteří jsou cílovou skupinou podpory.

Tento výzkum systému kolegiální podpory je první sondou do oblasti sociální opory bezpečnostního sboru, která, jak se ukázalo, nabídla několik směrů, kam lze směřovat následné hlubší bádání a poznávání. Výzkum zkoumal systém kolegiální podpory z hlediska jejich 
poskytovatelů. Jako užitečné vnímá autorka výzkumu jeho rozšíření o úhel pohledu ze strany samotných uživatelů podpory, tedy řadových policistů. Digliani (2018) navrhl dotazník, kterým se snažil zjistit, jak kolegiální podporu vnímají samotní policisté (kdy, proč a jak ji využívají). Tento dotazník by byl přeložen, upraven na české reálie a použit za stejným účelem. Došlo by tak ke komplexnímu zmapování systému kolegiální podpory z obou jejích stran.

Výsledky výzkumu přinesly zjištění, že poskytovatelé kolegiální podpory byli již tzv. vrbami ve svém okolí, to znamená, že nejspíše vykazovali znaky důvěryhodnosti či jiné osobnostní předpoklady. Kdo je tedy ta vrba z pohledu psychologie osobnosti? Jaký je to člověk? Mají tito lidé nějaké společné povahové rysy či predispozice? Výzkum z oblasti poznání a popisu osobnosti poskytovatele by přinesl užitečné poznatky k možnému budoucímu přesnějšímu výběru poskytovatelů a zároveň jejich většímu porozumění. Prakticky napříč celou prací se prolínají dvě témata, která jsou svébytně spjata a rezonují v policejní organizaci, a to nedůvěra a stigmatizace psychických poruch či psychické nepohody jako takové. Bylo zajímavé se podívat na to, jak ve skutečnosti vznikají, co bylo či je jejich spouštěči a co je upevňuje a posiluje. Výsledné poznatky by vedly k hlubšímu porozumění těmto dvěma fenoménům a prŕípadně by přinesly návrhy, jak tento status quo prolomit.

\section{Závěr}

Výzkum přinesl zjištění, že kolegiální podporu si policisté poskytovali i přirozeně předtím, než byl systém oficiálně zaveden. Nicméně se jednalo o laickou pomoc mnohdy na úkor poskytovatele. Školení jim proto přineslo úlevu nad tím, že řešení problémů kolegů neleží na jejich bedrech a nejsou za ně zodpovědni. Zároveň jim nabídlo několik možnosti podpory, na problémy druhých tedy přestali být sami. I přes to zde existuje stále spoustu bariér (strach o ztrátu zaměstnání, nedůvěra v kolegiální podporu, zlehčování jejího smyslu, mýtus nezlomného policisty), které ještě pravděpodobně potřebují čas na to, aby byly z velké části odstraněny a překonány. $\mathrm{K}$ tomu by mohla dopomoci lepší propagace systému podpory, a to zvláště ve vysvětlování jeho smyslu a cílů vedoucím pracovníkům. Pozitivním krokem by byl také vznik etického kodexu, coby formální kodifikace a náležitosti mlčenlivosti poskytovatelů.

\section{Literatura}

Alexander, D. A. \& Walker, L. G. (1994). A study of methods used by Scottish police officers to cope with work-induced stress. Stress Medicine, 10, 131-138. https://doi.org/10.1002/smi.2460100210

Burger, N. (2012). Vodítka, psychosociální podpora pro pracovníky uniformovaných složek. Nizozemí: Impact. https://www.mvcr.cz/clanek/psychosocialni-podpora-prouniformovane-slozky.aspx

Chan, J. (1996). Changing police culture. British Journal of Criminology, 36(1), 109-134. https://doi.org/10.1093/oxfordjournals.bjc.a014061

Chan, J. (2007). Police stress and occupational culture. Sociology of Crime, Law and Deviance, 8, 129-151. https://doi.org/10.1016/S1521-6136(07)08005-0 
Collins, P. \& Gibbs, A. (2003). Stress in police officers: A study of origins, prevalence and severity of stress-related symptoms within a county police force. Occupational Medicine, 53, 256-264. https://doi.org/10.1093/occmed/kqg061

Creamer, M. C., Varker, T., Bisson, J., Darte, K., Greenberg, N., Lau, W., \& Watson, P. (2012). Guidelines for peer support in high-risk organizations: An international consensus study using the delphi method. Journal of Traumatic Stress, 25(2), 134-141. https://doi.org/10.1002/jts.21685

Digliani, J. A. (2015). Contemporary Issues in Police Psychology: Police Peer Support Team Training and the Make It Safe Police Officer Initiative. Xlibris Corporation.

Digliani, J. A. (2014). Police and Sheriff Peer Support Team Manual. Dostupné z http://post.nv.gov/uploadedFiles/postnvgov/content/Training/PST\%20Manual\%203rd\%20 E-version.pdf

Digliani, J. A. (2018). Peer Support: Does it work? The Efficacy of Law Enforcement Peer Support. Peer Support Team Utilization and Outcome Survey Report. Fort Collins, Colorado. Dostupné z: http://www.jackdigliani.com/uploads/3/4/5/1/34518973/peer_support_team_survey_report.pdf

Duxbury, L. \& Higgins, C. (2012). Caring for and about those who serve: Work-life conflict and employee wellbeing within Canada's police departments. Sprott School of Business,

Carleton University.

Grauwiler, P., Barocas, B., \& Mills, L. G. (2008). Police peer support programs: current knowledge and practice. International Journal of Emergency Mental Health, 10(1), 27-38.

Hendl, J. (2005) Kvalitativní výzkum: Základní metody a aplikace. Praha: Portál.

Karaffa, K. \& Tochkov, K. (2013). Attitudes toward seeking mental health treatment among law enforcement officers. Applied Psychology in Criminal Justice, 9(2), 75-99.

Křivohlavý, J. (2001). Psychologie zdraví. Praha: Portál.

Link, B.G. \& Phelan, J.C. (2001). Conceptualizing stigma. Annual Review of Sociology, 27, 363-385. https://doi.org/10.1146/annurev.soc.27.1.363

McCreary, D.R. \& Thompson, M.M. (2006). Development of two reliable and valid measures of stressors in policing: The operational and organizational police stress questionnaires. International Journal of Stress Management, 13(4), 494-518. http://dx.doi.org/10.1037/1072-5245.13.4.494

McGuffin, M. (2018). Police culture: does culture prevent proper policing? University of Alaska Fairbanks. Non-Thesis Research Project.

Miovský, M. (2006). Kvalitativní př́stup a metody v psychologickém výzkumu. Praha: Grada.

Pienaar, J., Rothmann, S. \& van de Vijver, F.J.R. (2007). Occupational stress, personality traits, coping strategies, and suicide ideation in the South African police service. Criminal

Justice and Behavior, 34(2), 246-258. https://doi.org/10.1177/0093854806288708

Resnick, S. G., \& Rosenheck, R. A. (2008). Integrating peer-provided services: A quasiexperimental study of recovery orientation, confidence and empowerment. Psychiatric Services, 59, 1307-1314.

https://ps.psychiatryonline.org/doi/full/10.1176/ps.2008.59.11.1307

Shearing, C.D. \& Ericson, R.V. (1991). Culture as figurative action. The British Journal of Sociology, 42(4), 481-506. https://doi.org/10.2307/591444

Violanti, J.M. \& Aron, F. (1995). Police stressors: Variations in perception among police personnel. Journal of Criminal Justice, 23(3), 287-294. https://doi.org/10.1016/00472352(95)00012-F

Violanti, J. M. (2007). Police Suicide : Epidemic in Blue. Springfield, Ill: Charles C Thomas. 
Voska, V. (2017). Výroční zpráva 2016 oddělení vedoucího psychologa Policejního prezidia $\check{C} R$. Praha: Policejní prezidium České republiky.

Waters, J. A. \& Ussery, W. (2007). Police stress: History, contributing factors, symptoms, and interventions. Policing: An International Journal of Police Strategies \& Management, 30(2), 169-188. https://doi.org/10.1108/13639510710753199

White, A. K., Shrader, G., \& Chamberlain, J. (2016). Perceptions of law enforcement officers in seeking mental health treatment in a right-to-work state. Journal of Police and Criminal Psychology, 31(2), 141-154. https://doi.org/10.1007/s11896-015-9175-4

\section{Údaje o autorce}

Mgr. et Mgr. Petra Karbanová vystudovala obor Psychologie na FF UK a Mediální studia na FSV UK. V současné době působí jako policejní psycholog Středočeského kraje.

Kontaktní údaje

Adresa: Policie ČR - Krajské ředitelství policie Středočeského kraje, Na Baních 1304, 15600

Praha-Zbraslav

Email: petra.karbanova@email.cz

Karbanová, P. (2019). Systém kolegiální podpory Policie ČR. E-psychologie, 13(2), 13-32.

https://doi.org/10.29364/epsy.341 